Е. Ю. Дрожжина. Уроки милосердия в анималистических стихах С. А. Есенина 1910-х гг.

\author{
Научная статья \\ УДК 821.161 .1 \\ DOI: $10.18101 / 2686-7095-2021-1-49-54$
}

\title{
УРОКИ МИЛОСЕРДИЯ В АНИМАЛИСТИЧЕСКИХ СТИХАХ \\ С. А. ЕСЕНИНА 1910-х гГ.
}

\author{
(C) Дрожжина Евгения Юрьевна \\ кандидат филологических наук, \\ Елецкий государственный университет им. И. А. Бунина \\ Россия, 399770, Липецкая область, г. Елец, ул. Коммунаров, 28 \\ ekri84@mail.ru
}

\begin{abstract}
Аннотация. В статье анализируются ранние произведения С. А. Есенина на анималистическую тему. Обозначение «анимализм» употребляется применительно к произведениям изобразительного искусства, но может использоваться и в области словесного искусства. Доказывается, что стихотворения поэта, наполненные уникальным чувством преклонения перед всеми живыми существами на Земле, глубоко новаторски решают эту тему, традиционную для русской классической литературы. Показано, что в раннем поэтическом творчестве Есенин обращается к образам различных представителей животного мира: ими становятся корова и собака, не успевшие порадоваться прекрасному состоянию в их судьбе - светлому материнству, дикая лисица, чудом уцелевшая от смертельного выстрела. Думы и чувства прекрасных лошадей вырастают в душе лирического героя до чувства более высокого содержания - любви к родине. Утверждается, что стихотворения Есенина о животных звучат гимном родной земле в ее единстве с космосом.
\end{abstract}

Ключевые слова: анималистические стихотворения; образы животных; природный мир; контраст; уподобление человеку; психологизм.

\section{Для цитирования}

Дрожжина E. Ю. Уроки милосердия в анималистических стихах С. А. Есенина 1910-х гг. // Вестник Бурятского государственного университета. Филология. 2021. Вып. 1. С. 49-54.

Любовь ко всему живому на Земле буквально пронизывает каждую лирическую строку есенинского поэтического наследия. Его анималистические стихи, которые в связи с этим трактоваться как «жанр, в котором главным мотивом является изображение животных» [7], наиболее полно и гармонично передают неиссякаемое любовное чувство Есенина к «братьям нашим меньшим».

Главными «героями» произведений Есенина анималистической тематики становятся четвероногие друзья в стихотворениях «Корова» (1915), «Табун» (1915), «Лисица» (1916), «Песнь о собаке» (1915). Данные стихотворения не продолжают развивать лучшие классические традиции, заложенные писателями XIX-XX вв., с большой эмоциональной силой писавшими о животных: Л. Н. Толстым, И. С. Тургеневым, А. П. Чеховым, А. И. Куприным. Развивая и углубляя лучшие предшествующие традиции, поэт очеловечивает чувства животных. Так, Есенин может передать трагедию, горе живого, но не человеческого существа, придать этому чувству вселенский, космический размах. Л. В. Занковская отмечает: «Эти стихи можно назвать психологическими этюдами, где автор, использовав прием 
антропоморфизма, исследует душевное состояние животных, оказавшихся в критических ситуациях. Чтобы подойти к данной проблематике, автору нужно было досконально знать жизнь этих животных, их привычки и характер» [4, с. 59].

Одним из первых произведений, в котором ярко зазвучал голос Есенинаанималиста, стало стихотворение «Корова» (1915). С неподдельным состраданием автор описывает трагедию матери, не увидевшей своего дитя - белоногого телка. Искренним, будто человеческим, горем наполнена каждая лирическая строка, передающая душевную боль и скорбь, невыразимое страдание живого существа: «Не дали матери сына, / Первая радость не впрок. / И на колу под осиной / Шкуру трепал ветерок» [2, с. 87].

Есенин смог выразить внутреннее состояние своей героини, ее переживания, связанные с ситуацией безысходности и трагичности происходящих в ее судьбе событий: «Думает грустную думу / О белоногом телке» [2, с. 87]. Психологизм стихотворения проявился в изображении душевной опустошенности и горя матери, усугубляющихся другой не менее драматичной ситуацией - предчувствием собственной скорой кончины: «Свяжут ей петлю на шее / И поведут на убой» [2, c. 87].

На примере своей четвероногой героини Есенин показывает, что животному, как и человеку, свойственны душевные порывы и сомнения. Коренное отличие «братьев наших меньших» в том, что они всегда бесхитростны в своих влечениях и поступках. Поэт смог ярко передать чувства и настроения коровы. Его стихотворение наполнено красками, живописующими трагедию животного, страдающего от безнаказанности и жестокости окружающего человеческого мира. Отсутствие пафосных слов и восклицаний соответствует течению есенинского стиха, подобного ритму самой жизни с безвозвратностью ее утраченных реалий. Однако при всем трагизме изложенной Есениным ситуации светлыми настроениями проникнута концовка стихотворения, возвращающая читателя в светлый мир грез и уходящего теплого лета: “Снится ей белая роща / И травяные луга» [2, с. 88]. Драматичная ситуация безысходности согрета светом природного мира. Корова, сама являющаяся плотью земли, вновь возвращается в ее согревающее лоно. Именно в живой органической связи с природным миром существование коровы находит свой первоначальный, извечный смысл, чуждый враждебному человеческому миру, отнявшему сына, лишившему светлой радости материнства.

Суровой правдой о бессердечности законов людского мира проникнуто и другое стихотворение - «Песнь о собаке» (1915), ставшее своеобразной визитной карточкой Есенина-анималиста. Это произведение представляет собой правдивую зарисовку из жизни дворовой собаки. Поэт сообщает нам о рожденных ею «рыжих семерых щенятах». С первых строк Есенин вводит в уютный мир, согретый материнской теплотой и любовью. Сила и безграничность чувств материсобаки переданы в нескольких строках: «До вечера она их ласкала, / Причесывая языком, / И струился снежок подталый / Под теплым ее животом» [2, с. 145]. Животное согрето радостью материнства, делая все для того, чтобы ее детенышам было уютно и тепло. «Хозяин хмурый» нарушает идиллию и радость материнских чувств: топит щенят. Есенин описывает неимоверные страдания живого существа, молчаливую мольбу матери пощадить своих детей: «По сугробам она бежала, / Поспевая за ним бежать ...» [2, с. 145]. 
Е. Ю. Дрожжина. Уроки милосердия в анималистических стихах С. А. Есенина 1910-х гг.

Собака убеждается в жестокости и несправедливости человеческого мира, ее грусть и отчаяние не знают границ. Природное бытие, органичной частью которого и является собака, лишь напоминает ей о невозвратимости утраченного ее мимолетного счастья материнства: «B синюю высь звонко / Глядела она скуля, / А месяи скользил тонкий / И скрылся за холм в полях» [2, с. 146]. Страдания собаки безграничны. Поэт смог найти слова, передающие острую боль животного, навеки потерявшего своих детенышей: «И глухо, как от подачки, / Когда бросят ей камень в смех, / Покатились глаза собачьи / Золотыми звездами в снег» $[2$, c. 146$]$.

Стих Есенина вызывает живое сочувствие к горю собаки, заставляет переживать ее скорбное чувство как глубокое, по-человечески пронзительное. Л. В. Занковская поясняет сам масштаб этого чувства: «Горе матери в стихотворении автор рассматривает в масштабе макрокосма. Зло, совершенное человеком по отношению к собаке и ее детям, не может быть оправдано ни с каких позиций. Как страшно, что человек забыл заповеди Божьи, и главную из них: “Не убий”. Содеянное "хозяином хмурым", убежден поэт, разрушает гармонию целого мира» $[4$, c. 66$]$

Главными героями анималистической лирики Есенина становятся не только домашние животные. Глубокую скорбь вызывают у поэта страдающие дикие звери. Так, в стихотворении «Лисица» (1916) героиня наделена человеческими качествами, хотя сталкивается с бессердечностью этого человеческого мира. С первых строк Есенин вводит в ситуацию, связанную с жестокостью охотника, подстрелившего лисицу: «На раздробленной ноге приковыляла, / У норы свернулася в кольио. / Тонкой прошвой кровь отмежевала / На снегу дремучее лиио» [2, с. 108].

Поэт заостряет внимание на последующем состоянии лисицы, сумевшей скрыться от погони. Подобно человеческому существу, героиня остро переживает случившуюся с ней беду. Уже в норе ей мнится звук выстрела и последующая острая боль. Воспоминания относят лисицу в ту роковую минуту, когда она, испуганная и уставшая от боли и страха, стремилась в свой маленький мир - темную нору, ставшую защитой от человеческой злобы. Есенин рисует картину, наполненную звуками, красками, ощущениями. Ситуация достоверности за счет присутствия лирического субъекта достигается при помощи контраста - картин пожара и холодного снега: Желтый хвост упал в метель пожаром, / На губах как прелая морковь... / Пахло инеем и глиняным угаром, / А в ощур сочилась тихо кровь [2, с. 108].

Использование поэтом эпитета «дремучий» позволяет показать «всю грусть и боль животного, его ожесточение против того мира, который принес столько горя» [3], и контекст его употребления подчеркивает противостояние мира людей, проливающего кровь зверей, и мира природного, более древнего, обладающего лицом чуть ли не вечным - лицом самой природы.

Эти и подобные образы братьев наших меньших в раннем творчестве Есенина существуют на фоне повседневного бытия. Благодаря емким есенинским картинам читатель знакомится с бытом и атмосферой существования диких и домашних животных. В небольших поэтических зарисовках Есенин рассказывает о судьбе своих героев или описывает мимолетные, но значимые эпизоды их бытия. Анализ трех данных анималистических зарисовок дает также возможность гово- 
рить о психологическом наполнении образов. Как заключает Л. В. Занковская по этому поводу, «звери в анималистских элегиях заняли самостоятельное место. Эти стихи стали для поэта хорошей школой, они помогли ему в совершенстве освоить прием психологизма, ставший затем неотъемлемой частью его классики» $[4$, c. 74$]$.

Интересной кажется мысль В. Леденева о том, что многие стихотворения Есенина о животных создавались в период военных действий. По мысли исследователя, этот момент не случайное совпадение, что «в очередной раз напоминает о том, что следует осуждать зло и насилие и хранить в своем сердце и на земле добро и человечность» [3].

Искренним чувством любви к миру животных проникнуто стихотворение Есенина «Табун» (1915). Поэт описывает вдохновенную красоту любимых им лошадей: «В холмах зеленых табуны коней / Сдувают ноздрями златой налет со дней. / С бугра высокого в синеющий залив / Упала смоль качающихся грив» [2, с. 91]. В описаниях животных Есенин остается верен себе, выбирая слова и краски, отождествляющие зверей и человека, делающие их почти равными в сложном и многообразном природном бытии. Поэтому у Есенина животные, подобно человеческому существу, страдают и радуются, думают и мечтают, смеются и плачут. Наблюдая за вольным табуном коней, восхищаясь их красотой и величием, Есенин старается уловить думы прекрасных лошадей, доносит до читателя чувство более высокого содержания - невыразимую любовь к своей родине. Гимном родной земле поэт завершает стихотворение: «Любя твой день $u$ ночи темноту, / Тебе, о родина, сложил я песню ту» [2, с. 92].

Особенность лирического «я» Есенина и его собственного поэтического голоса наиболее полно и ярко проявилась в любви к животным как неотъемлемой части единого мирового «организма». В. А. Игнатьев в этой связи справедливо отмечал: «Использование образов животных позволяет Есенину через сравнения, сопоставления выразить чувство патриотизма, глубокую любовь к Родине, к ее могучему взлету в будущем» $[5$, с. 40$]$. Братья наши меньшие в произведениях Есенина сродни человеку, поэт пишет о них с неповторимой любовью и сочувствием. Известна реакция Горького на проникновенную «Песнь о собаке»: «...Он [Есенин. - E. Д.] первый в русской литературе так умело и с такой искренней любовью пишет о животных» [1, с. 309].

Подобное отношение к животным («И зверье, как братьев наших меньших, / Никогда не бил по голове») характеризует лирического героя как человека искреннего, доброго, чуткого, сердечно отзывчивого. Анализ анималистических стихотворений Есенина позволил Е. Н. Наумову справедливо заметить об авторе: «Эти стихи человека, любящего все живое, смотрящего на мир как на единое целое. Как на детей одной матери-земли, он смотрел на человека, на природу, на животных» [6, с. 50].

Лирический герой ранних поэтических свершений Есенина органично вписан в пространство природных реалий. Он слит воедино с «живой многоголосной прелестью» земли, чувствует себя неотьемлемой частью природного мира. Духовная гармония внутреннего мира лирического «я» прозревается «через» гуманное отношение к «братьям нашим меньшим», лучшим друзьям человека. 
Е. Ю. Дрожжина. Уроки милосердия в анималистических стихах С. А. Есенина 1910-х гг.

Многих исследователей привлекали анималистические стихотворения Есенина. Так, И. Н. Розанов писал о своих впечатлениях после чтения ряда есенинских произведений: «Тут были стихотворения, понравившиеся мне целиком, например, "Корова", где уже сказалась столь характерная для позднейшего Есенина нежность к животным. "Песня о собаке", написанная на однородную тему, конечно, лучше, но и здесь типичный мотив: “Для зверей приятель я хороший”... Кажется, в первый раз в русской литературе поэт привлекал внимание к горю коровы» [8, с. 121].

С ранних лет анималистическая тематика станет неотъемлемой в поэзии Есенина, о чем свидетельствует написанный им на закате творческих лет цикл лирических этюдов «Сестре Шуре», относимый к детской подростковой литературе. Своим неповторимым поэтическим отношением Есенин смело опроверг суждение известного философа А. Шопенгауэра, писавшего: «Человек в сущности есть дикое ужасное животное» [9, с. 37]. Осуждая беспричинное насилие со стороны человека над «братьями нашими меньшими», Есенин как никто иной воплотил чистоту и красоту звериных чувств в лирической ткани своего неповторимого поэтического творчества.

\section{Литература}

1. Горький М. Сергей Есенин // Жизнь Есенина / составление, вступительная статья и примечание С. П. Кошечкина. Москва: Правда, 1988. С. 306-311. Текст: непосредственный.

2. Есенин С. А. Полное собрание сочинений: в 7 т. Т. 1: Стихотворения. Москва: Наука; Голос, 1995. 672 с. Текст: непосредственный.

3. Животный мир в творчестве C. А. Есенина. URL: https://lit-helper.com/ p_jivotnii_mir_v_tvorchestve_s_a_esenina (дата обращения: 15.11.2020). Текст: электронный.

4. Занковская Л. В. Новый Есенин. Жизнь поэта без купюр и идеологии. Москва: Флинта, 1997. 416 с. Текст: непосредственный.

5. Игнатьев В. А. Счастье в поэзии и в жизни С. А. Есенина. Москва: Рос. филос. ово, 2002. 98 с. Текст: непосредственный.

6. Наумов Е. И. Сергей Есенин. Жизнь и творчество. Москва; Ленинград: Просвещение, 1965. 280 с. Текст: непосредственный.

7. Популярная художественная энциклопедия / гл. ред.: В. М. Полевой. Москва: ДиректМедиа Паблишинг, 2006. URL: https://biblioclub.ru/index.php?page=dict\&termin= 655316 (дата обращения: 15.11.2020). Текст: электронный.

8. Розанов И. Н. Воспоминания о Сергее Есенине // Жизнь Есенина / сост., вступ. ст. и прим. С. П. Кошечкина. Москва: Правда, 1988. С. 119-122. Текст: непосредственный.

9. Шопенгауэр А. Мысли. Санкт-Петербург: Азбука, 2020. 192 с. Текст: непосредственный.

Статья поступила в редакцию 24.11.2020; одобрена после рецензирования 28.01.2021; принята к публикации 25.03.2021.

\section{LESSONS OF MERCY IN S. A. ESENIN'S ANIMALISTIC VERSES OF 1910s}

Evgenia Yu. Drozhina

Cand. Sci. (Phil.),

Bunin Yelets State University

28 Kommunarov St., Yelets 399770, Russia

ekri84@mail.ru 
Abstract. The article reviews the early works by Sergei Yesenin on the animalistic theme. The designation "animalism" is used in relation to works of fine art, to paintings by artists, but it can also be used in reference to verbal art. The author claims that Yesenin's poems, filled with a unique sense of admiration for all living beings on earth, deeply innovatively solve this topic, which is traditional for Russian classical literature. The article shows that in his early poetic work Yesenin turns to the images of various animals: a cow and a dog who did not have time to rejoice in the wonderful state of their fate — bright motherhood, or a wild fox that miraculously survived a fatal shot. The thoughts and feelings of beautiful horses grow in the soul of the lyrical hero to a feeling of a higher content - love for the motherland. Yesenin's poems about animals sound like a hymn to the native land in its unity with the cosmos.

Keywords: animalistic poems; images of animals; natural world; contrast; psychologism.

For citation

Drozhzhina E. Yu. Lessons of Mercy in S. A. Esenin's Animalistic Verses of 1910s. Bulletin of Buryat State University. Philology. 2021; 1: 49-54 (In Russ.). C. 49-54.

The article was submitted 24.11.2020; approved after reviewing 28.01.2021; accepted for publication 25.03.2021. 